\title{
New Trends in Waste Management in the Selected Region of the Slovak Republic
}

\author{
Lucia Knapč́íková ${ }^{*}$, Miroslav Rimár ${ }^{2}$, Marcel Fedák ${ }^{3}$ \\ \{lucia.knapcikova, miroslav.rimar,marcel.fedak\} atuke.sk \\ 1* Technical University of Košice, Faculty of manufacturing technologies with a seat in Prešov, \\ Department of industrial engineering and informatics , Bayerova 1, 08001 Prešov, \\ Slovak Republic \\ ${ }^{2}$ Technical University of Košice, Faculty of manufacturing technologies with a seat in Prešov, \\ Department of process engineering, Štúrova 31, 08001 Prešov, \\ Slovak Republic \\ ${ }^{3}$ Technical University of Košice, Faculty of manufacturing technologies with a seat in Prešov, \\ Department of process engineering, Štúrova 31, 08001 Prešov, \\ Slovak Republic
}

\begin{abstract}
Plastic waste as a separate component (fraction) of waste management can be defined as waste from production and consumption. Waste from the production and is also characterized as industrial waste and waste from manufacturing processes. It formed directly in the production and finalization of the semi product. It is basically the best quality plastic waste. Its advantage is the fact that it is almost always a waste of single-well-defined and well-known material from which it is largely possible to do full recycling products. Recycling of this material type in Slovak republic is relatively well settled. Waste from consumption i.e. mainly waste from used products and packaging may occur on two levels and a waste eg. from supermarket chains, warehouse, industry (industrial packaging), waste from municipal sector.etc..
\end{abstract}

Keywords: plastics materials, recycling, waste management

\section{State of the art}

On the present, on the part of waste existence, it is not important look at the percentage of waste or that type, but the actual amount of waste expressed in mass units. [1] Separate fraction of plastics form in the municipal waste and their components can be further mechanically divided by several separate species. [1] , [2] Respect this fact supports the need for further waste sorting a plastic fraction, which is the basis for successful recycling. [2] State of the art about plastics waste management is a material point of composition view of the plastic components in municipal waste by mass on average. It is presented in the following Table 1. 
Table 1. Plastics in the municipal waste [1]

\begin{tabular}{|l|c|}
\hline Polyethylene (PE) & $65 \%$ \\
\hline Polypropylene (PP) & $9 \%$ \\
\hline Polystyrene (PS) & $9 \%$ \\
\hline $\begin{array}{l}\text { Polyethylene } \\
\text { terephthalate(PET) }\end{array}$ & $10 \%$ \\
\hline $\begin{array}{l}\text { Polyvinyl chloride } \\
\text { (PVC) }\end{array}$ & $1 \%$ \\
\hline Other* & $6 \%$ \\
\hline
\end{tabular}

To the "Other" belong here: polyamide (PA), Acrylonitrile butadiene styrene (ABS), polymethyl methacrylate (PMMA).

\section{Definition of plastics in the waste management}

Plastics are an important material, without which our daily life would not imagine. [1] They are used in the production of packaging materials, components, automotive and electronics industries, textiles and fabrics as well as in many other areas. [3] Large amounts of plastics are made from oil in petrochemical industry. Plastics, sometimes known as the plastic, communicated range of synthetic or semi synthetic polymerization products. [4] They are composed of organic condensation or the additive polymer, and often include other materials to improve the quality and price. There are few natural polymers generally considered to be plastics. [3],[4] Plastics can be molded into products, films or fibres. Many plastics are mouldable - have a feature called plasticity. Plastics are designed with great variability in properties such as heat tolerance, hardness, durability and so on. [5] Plastics are polymers, long chains of atoms attached to each other. These chains are made up of many repeating molecular units or "monomers." The great majority of plastics are composed of polymers of carbon alone or with oxygen, nitrogen, chlorine or sulphur in the chain. [1], [6] Development of plastics to the raw materials, continued use of chemically modified natural materials (e.g. natural rubber, nitrocellulose), and continues the production of a completely synthetic molecule (e.g. polyvinyl chloride, polyethylene and the like.).

There are three main groups of plastics:

- Thermoplastics,

- Thermosets,

- Elastomers [5] 
Thermoplastics are compound from linear or branched polymeric bond that are soften by heating, cooling will take over the original strength. After melting them can be reprocessed or reworked. Thermosets composed of liquid monomer retains some consistency over limit temperature, characteristic for each species of these plastics. After melting, are not recoverable. Elastomers are comprised of branched polymers, at normal temperature have a degree of flexibility such as rubber. The heat reactive thermosets like. [3], [5] Recycle can only be a first group of plastics, namely thermoplastics. The remaining two groups can be assessed only as waste by pyrolysis (thermal decomposition, which can be obtained from fuels, solvents and other recyclable products) or incineration. Plastics are increasingly being used in the packaging industry. Currently, in Europe, are packaged in the plastic about $50 \%$ of products. [7]Among the major "consumers" plastics include packaging industry, household, construction industry, agriculture, automotive, electrical and electronics industry. Consumption of plastics currently still growing and it can be assumed that it will continue to grow well. In general we can say that plastics are one of the most important materials. [1], [3]The main reasons for such a large and continuous expansion of the use of plastic materials are:

- the plastics is a substance of low density, yet reduces the overall weight of the product,

- the plastics exhibit low thermal and electrical conductivity, therefore, are often used as insulating materials,

- plastics are easily molded - plastics are usually highly resistant to corrosion, and are characterized by low degradability (aging).

Plastics waste produced in the manufacture, treatment or use in industry and in the social and individual consumption as a municipal waste.

\section{Waste management in the Prešov region}

Charging of the plastics sector does not include all plastic, or all the products of the charge plastics. Respectively part of the range of plastic products will be paid the contribution to other sectors of the Recycling Foundation of the Slovak republic (Fig.1, Fig.2), for example in the sectors of industry and electrical and electronic equipment. Waste Law Nr.79/2015 according to Slovak republic Law, was applicable only partly material and partly manufactured principle. [1], [2]For the various electric equipment and automobiles, the contribution paid for the equipment as a complete set regardless of what the components of the material composition comprises, other than e.g. tires and batteries need to be paid separately. [7] 


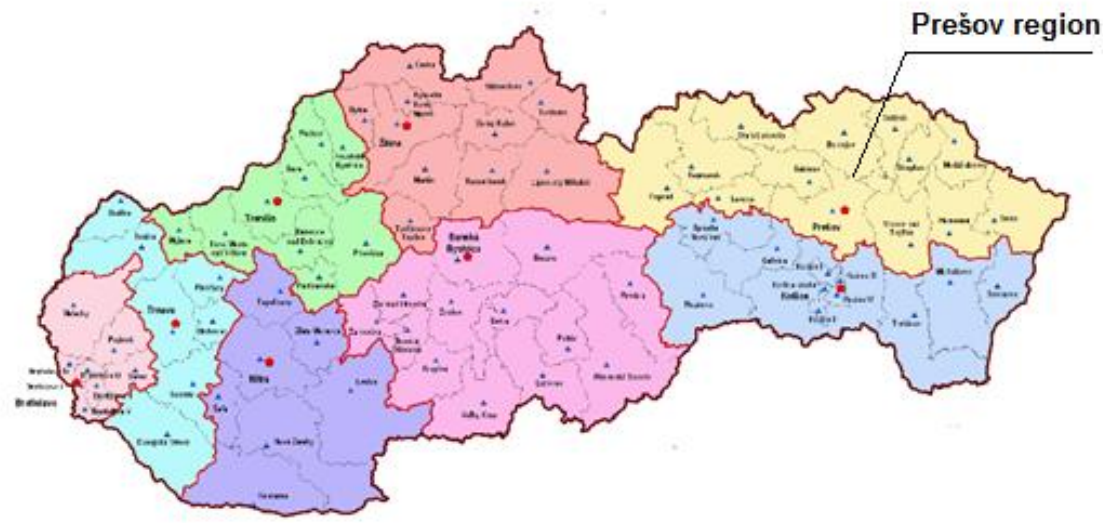

Fig.1. Map of the Slovak republic

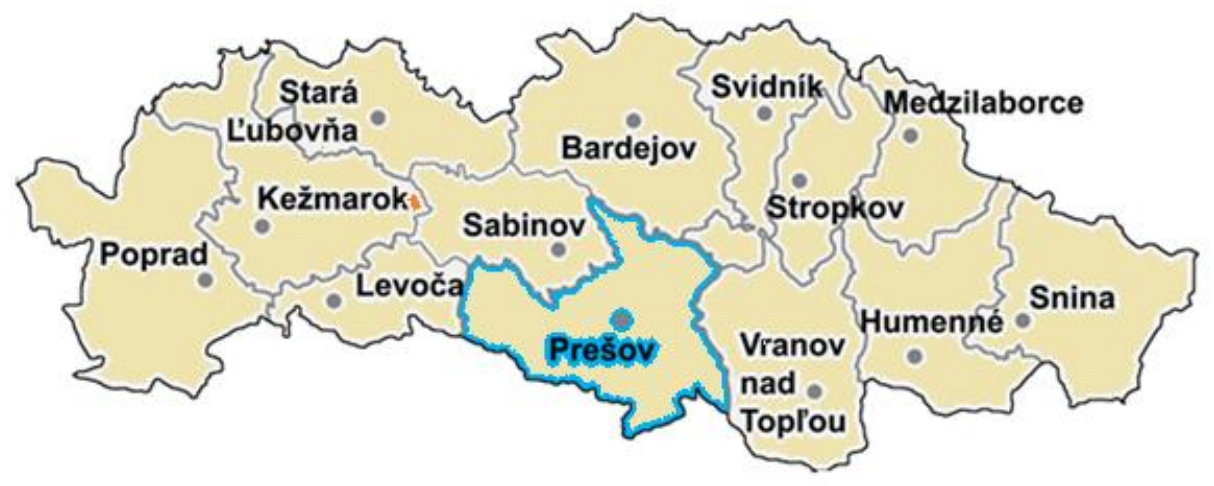

Fig. 2. Map of the Prešov region of the Slovak republic

On the other hand, household waste, does not come part of the charge products (mainly PE containers, plastic films, packaging films for group packaging, etc.), assigned mainly to supermarket chains (Table 2.) They are collected under separate harvesting systems as single waste. 
Table 2. Waste management in the Prešov region

\begin{tabular}{|c|c|c|c|c|c|}
\hline$\stackrel{g}{\dot{z}}$ & 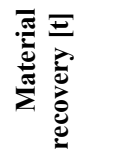 & bi: & 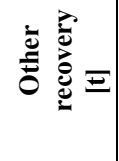 & 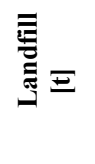 & 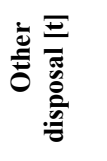 \\
\hline Bardejov & 25,24 & - & - & 0,67 & - \\
\hline Humenné & 149,33 & - & - & 0,26 & - \\
\hline Kežmarok & 18,60 & - & 209,90 & 99,20 & - \\
\hline Levoča & 139,03 & 1,00 & 27,00 & 3,00 & - \\
\hline Medzilaborce & 0,20 & - & - & - & - \\
\hline Poprad & 3443,00 & - & 453,00 & 314,00 & 27,00 \\
\hline Prešov & 626,00 & 10,00 & 44,00 & 241,00 & - \\
\hline Sabinov & 162,00 & - & 70,00 & 208,00 & - \\
\hline Snina & 660,20 & - & 22,00 & 6,00 & - \\
\hline Stará Lubovňa & 0,34 & - & 3,56 & 0,28 & - \\
\hline Stropkov & 7,07 & - & 0,80 & 34,90 & - \\
\hline Svidník & 40,98 & 0,50 & 0,60 & 0,41 & - \\
\hline Vranov nad Topl'ov & 246,00 & - & 70,00 & - & - \\
\hline $\begin{array}{l}\text { Prešov } \\
\text { Region }\end{array}$ & 5517,99 & 11,50 & 900,86 & $\mathbf{9 0 7 , 7 2}$ & 27,00 \\
\hline
\end{tabular}

Possibility of single waste recycling (for example PET bottles, part of PE films), their relatively easy separation and the possibility of obtaining exemption from the payment to Recycling Foundation of the Slovak republic (through the Lawful organizations) is unfortunately possible situations and so that the "other" waste will be increase, but sources in Recycling Foundation of the Slovak republic fee, will drop dramatically. [1],[7] 


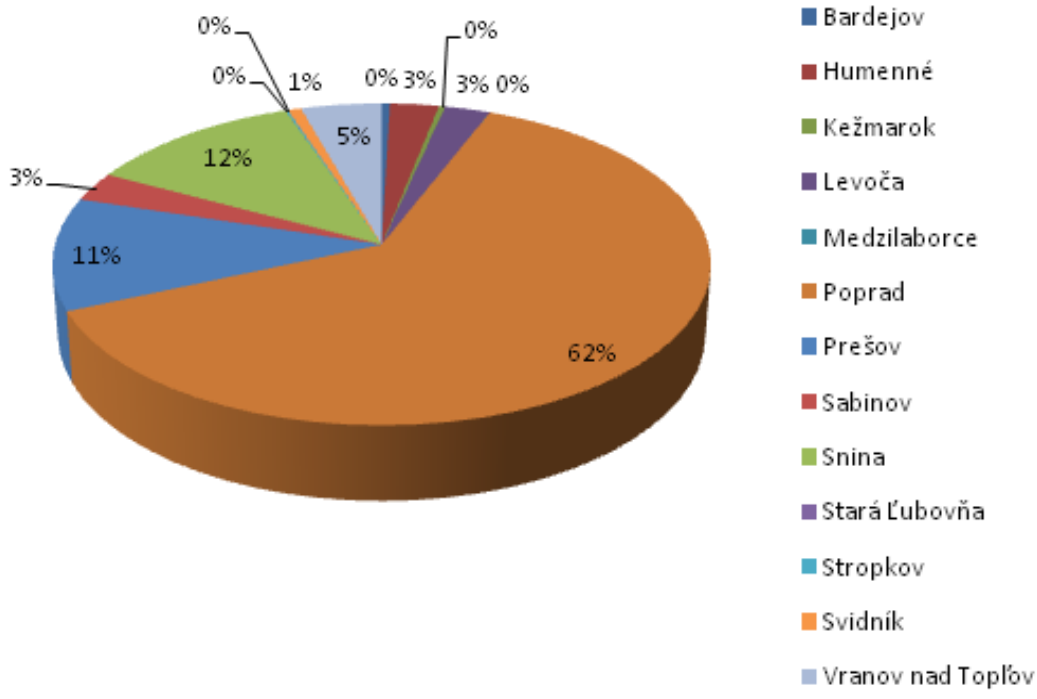

Fig. 3. Material recovery of plastics materials in the Prešov region

In the next figures (Fig.4-6) are presented results of waste management in the Prešov region for each of Prešov region tows. Figures presented a material and energy recovery of plastics materials in the Prešov region, other method of plastics recovery and landfill of course. 


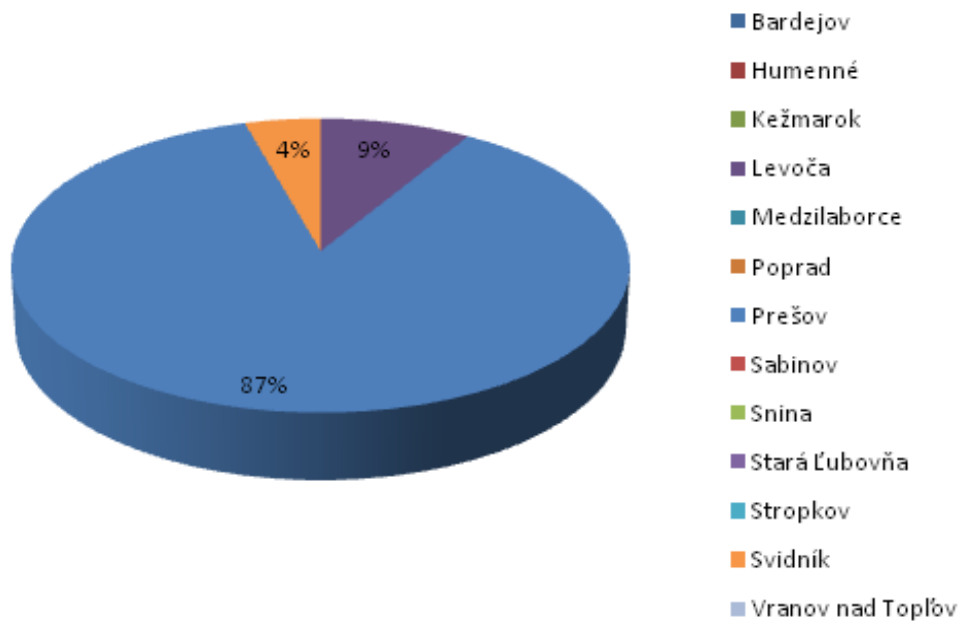

Fig. 4. Energy recovery of plastics materials in the Prešov region

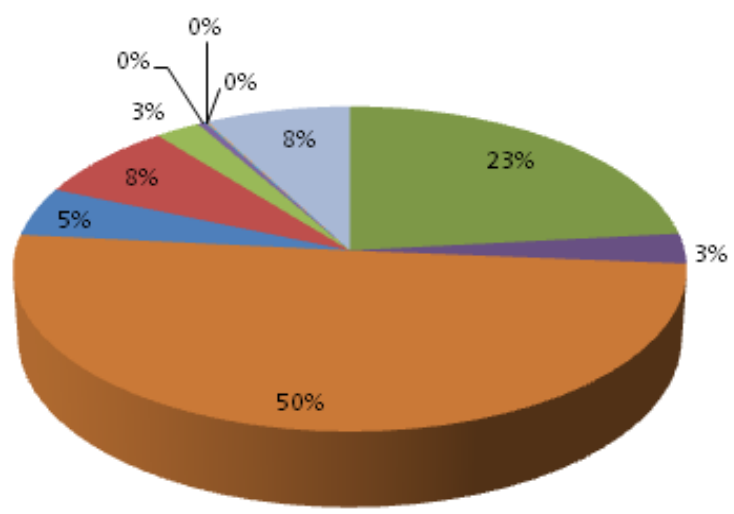

- Bardejo

- Humenné

- Kežmarok

- Levoča

Medzilaborce

- Poprad

- Prešov

-Sabinov

- Snina

- Stará L’ubovňa

astropkov

" Svidník

Vranov nad Toplov

Fig. 5. Other recovery of plastics materials in the Prešov region 


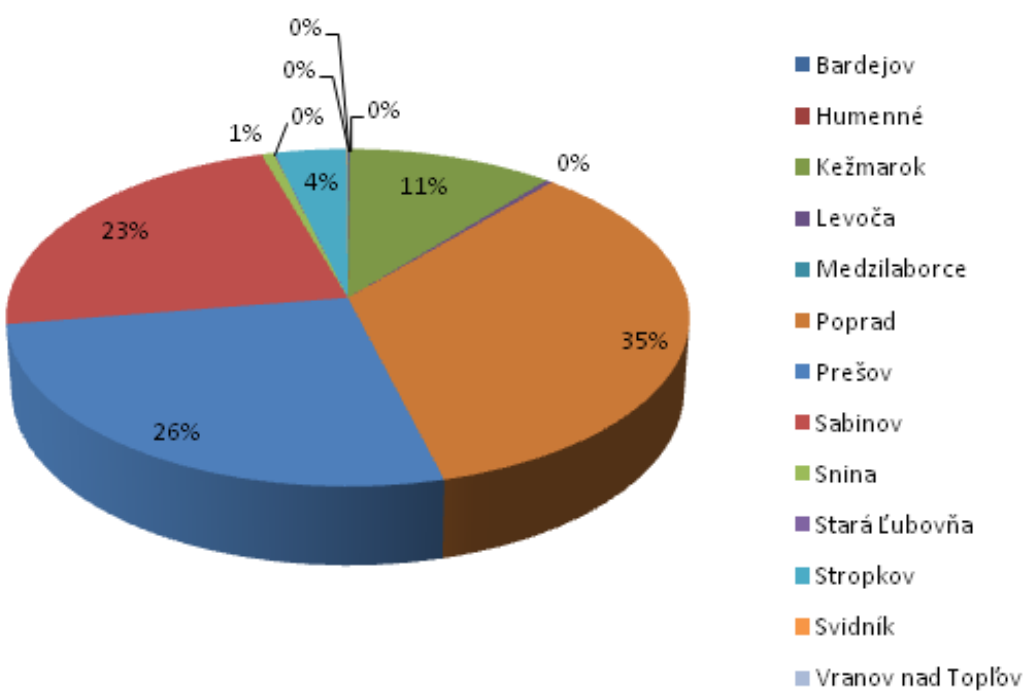

Fig. 6. Landfill of plastics materials in the Prešov region

With unchanged current trend can be expected that the plastic waste will prevail in the future, especially those products and charged that vary from contaminated especially food scraps. In particular, the cups and bowls from polypropylene and polystyrene to various fermented products and salads, a bottle of drugstore and cosmetics industry.

\section{Conclusion}

The study deals with plastic waste in the Prešov region. It is known, the most plastic waste has Poprad district and the lowest waste plastic producing is in the Medzilaborce district. Plastic recovery in the region has still many shortcomings that need to be improved. Energy recovery of plastics is low, the consequence of the low utilization of plastics waste to this method. Another problem is useless plastic waste landfill, which could be evaluated differently. However, with the improvement of the aforementioned recovery of plastic waste in the Prešov region should focus on sorting plastic waste and its subsequent waste sorting. 


\section{References}

[1] Ministerstvo vnútra SR;. Program odpadového hospodárstva Prešovského kraja na roky 2011-2015 [Online],[2016-04-20].Available on www $<$ http://www.minv.sk/?odpadove-hospodarstvo-1\&subor $>$.In slovak

[2] Barry,C.M.F., "Processing of thermoplastics", In: Harper, CH.A.: Modern Plastics Handbook, USA, ISBN 0-07-026714-6 (2011)

[3] Asplund, J.:Scrap Rubber- An Unpredicatble Waste of Useful Raw Material.(2013)

[4] Knežo, K.: Application of the numerical methods for the teaching of the statistics. In: International Journal of Interdisciplinarity in Theory and Practice. No. 5, p. 5861. - ISSN 2344-2409 (2014)

[5] Hutyrová Z. et al. Study of Surface Roughness of Machined Polymer Composite Material. In: International Journal of Polymer Science. Vol. 2015,

p. 1-6. - ISSN 1687-9422. (2015)

[6] Oravec,P., Vojteková D.: Technické spracovania odpadov-1. vydanie.-PO: TUFVT. ISBN 80-7099-783-4.(2002).In Slovak

[7] Matel et al. Informačný súhrn vybraných faktorov ovplyvňujúcich a podporujúcich rozvoj separovaného zberu a recyklácie plastov v SR, 2005, [Online] Available on www: $<$ http://www.recfond.sk/index.php?www=sp_file\&id_item=83>.In slovak

[8] Wang, W., Koren, Y. Scalability planning for reconfigurable manufacturing systems. Journal of Manufacturing Systems 31, p.83-91. (2012) 